\title{
Relations Between Parenting Styles and Learning Motivation with Social Science Learning Outcomes
}

\author{
Dinari Widoresmi, Zaenal Abidin \\ Primary School Teacher Education Department, Faculty of Education, Semarang State University, Indonesia \\ Corresponding email: dinariwid@gmail.com
}

\begin{abstract}
This research was backgrounded by preliminary research data. It was found that parents were busy working, students were not enthusiastic in learning process, and social science learning outcomes was not optimal. This aim of researchis toreveal the correlation of parenting patterns and learning motivation with Social Science learning outcomes. This type of research is a correlational quantitative research with sample amount of 136 students taken using the quota sampling. Data collection techniques used interview, questionnaires, and documentation. In addition, data analyses used descriptive statistical analysis, product moment correlation, multiple correlation, simple and mutiple regression. The results showed that there were positive and significant correlation between parenting patterns and social science learning outcomes amount of 0.736 , learning motivation and social science learning outcomes amount of 0.725 , parenting patterns and learning motivation simultaneously with social science learning outcomes amount of 0.805 , contribution of parenting patterns with social science learning outcomes amount of $54.2 \%$, contribution of learning motivation with social science learning outcomes amount of $52.5 \%$, contribution of parenting patterns and learning motivation with social science learning outcomes amountof $64.9 \%$. Those can be concluded that there are positive and significant correlation between parenting patterns and learning motivation with Social Science learning outcomes of fourth-grade students in Primary School, Group of Ki Hajar Dewantara, South Kaliwungu Subdistrict, Kendal Regency.
\end{abstract}

Keywords: Learning motivation; Parenting patterns; Social Science learning outcomes.

\section{Introduction}

Education plays important role and influences individual and people development and civilization of a nation. Education is able to develop the potentials of individuals at best. This is in line with Undang-Undang No.20 tahun 2003 (Act:20/2003) on National Education System Chapter II article 3 that states that: "Pendidikan nasional berfungsi mengembangkan kemampuan dan membentuk watak serta peradaban bangsa yang bermartabat dalam rangka mencerdaskan kehidupan bangsa, bertujuan untuk berkembangnya potensi peserta didik agar menjadi manusia yang beriman dan bertakwa kepada Tuhan Yang Maha Esa, berakhlak mulia, sehat, berilmu, cakap, kreatif, mandiri, dan menjadi warga negara yang demokratis serta bertanggung jawab (National Education has function to develop individual competencies and to build characters and dignitious civilization of a nation in order to develop nation's intellectual life that aims to develop the students' potentials in order to become faithful and pious to The One and Only God, have good character, be healthy, be knowledgeable, be skillful, be creative, be independent, and be democratic as well as be accountable human).

In Indonesia there are three types of education, i.e. formal, informal and non-formal one. Regulation of Government of Republic of
Indonesia: 17/2010 article 1 verse 39 states that informal education is the type of education that involves family and the neighborhood. In order to achieve the purpose of national education, the government also promotes the formal education. Regulation of Government of Republic of Indonesia: 17/2010 article 1 verse 6 states that formal education is gradual and structured education comprising primary and secondary, high-school, and higher education. Primary school as one of formal education institution plays important role in providing the students with basic competencies such as knowledge, skills, and behavior through the learning process. The curriculum structure of primary school (SD/MI) under PP:32/2013 article 77i on amendment to Regulation of Government:19/2005 on national standards of education requires the teaching of Social Science (IPS) subject.

Three educational spaces that will build the children in the complete human are family, school, and surrounding people. Family is the beginning of the children's development. The family has dominant role in building a child into intelligent, healthy, and adaptive one. Family is one of the main determinants in terms of a child's personality development beside the other factors (Helmawati, 2014). The parenting style and the behavior built into the child are relatively constant from time to time. This 
behavior can be felt by the children and can create either positive or negative impacts (Djamarah, 2014).

The students, in terms of studying and the efforts to achieve the great future should be helped, not only by the teacher, but also by their parents because the parents are the main one who determines the children's learning success. The parenting style or the family in terms of educating and generating learning motivation plays significant role that can be new source for getting enthusiasm to the children, so that the students' learning motivation will improve, and their learning outcomes will improve, too. The motivation is important, not only to make the students do the learning activities, but also to determine how much the students can learn from the activities they do or from the information they get. The motivated students show the good cognitive process in terms of learning, absorbing, and memorizing what they have learnt (Rifa'i, 2012). The parenting style and learning motivation are related closely to the learning outcomes. It makes sense that the meaning of learning outcomes is the changes happening to the students concerning cognitive, affective, and psychomotor aspects as the results of the learning activities (Susanto, 2010).

The preceding research underlying me doing the research on this issue is the one conducted by Rini Harianti dan Suci Amin published by STIKes Al-Insyirah Pekanbaru in 2016 titled "Pola Asuh Orang Tua dan Lingkungan Pembelajaran Terhadap Motivasi Belajar Siswa" (The Impact of Parenting Styles and Learning Environment on Students' Learning Motivation). The study shows that parenting style has significant and positive impact on the students learning motivation at significance value 0.000 at coefficient determinant $69.1 \%$.

It was also strengthened by the study conducted by Farzana Bibi, et.al. in 2013 titled "Contribution of Parenting Style to life domain of Children". The research shows that the parents have significant impact on the children's whole lives which means that from birth to adult periods of the children are influenced by their parents. The children spend most of their time at home and their parents' behavior, attitude, life standard, and communication way with them have significant impact on their future lives. If their parents were too strict or too permissive, they would cause bad impact to their lives. If their parents, however, were supportive, attentive, and flexible, they would be healthy psychologically and mentally.

Based on the observation and the interviews that I made, I found some issues, such as: (1) The teacher of SD Negeri Gugus Ki Hajar Dewantara in Kendal Regency said that many students still found it hard to comprehend the lesson materials particularly those of Social Science subject. It is caused by numerous lesson materials to memorize, such as history, blind map, the Indonesian cultures. (2) The students are less enthusiast during the teaching and learning process, particularly Social Science subject because the lessons of Social Science are uninteresting; (3) Most of the teaching tools that the teacher has applied only refers to the teacher's book which caused less exploration or enrichment of the lesson materials as additional references for the students to learn: (4) The percentage of students average Social Science learning outcomes were $46.3 \%$ which was below the mastery learning criteria.

\section{Research Method}

The research used qualitative research particularly correlative study. This study used independent variables (parenting styles and learning motivation) and dependent variable (Social Science learning outcomes). Population for this study was 216 grade IV students of SD Negeri Gugus Ki Hajar Dewantara Kendal Regency. The sampling method that I took was quota sampling, the samples of which are 136 students. Subject for this research was taken from SDN 1 Magelung, SDN 1 Protomulyo, and SDN 2 Protomulyo.

The data for this research were collected through questionnaire on parenting style and learning motivation, documentation for Social Science learning outcomes, as well as interviews with the teacher and the students. Before the research instruments were used, I had tested the validity of the instrument through product moment formula and had tested the reliability of the instrument through Cronbach Alpha formula. This study used descriptive statistic analysis, product moment correlation analysis, multiple correlations, simple linear regression, and multiple regressions.

\section{Results And Discussion}

The research on the relations of parenting styles and learning motivation with the learning outcomes of grade IV students of 
SDN Gugus Ki Hajar Dewantara Kabupaten Kendal investigated several issues such as: (1) descriptive analysis results of parenting styles, learning motivation, and Social Svience learning outcomes; (2) result of analysis precondition test; (3) result of hypothesis testing.

\section{Results of Descriptive Analysis Descriptive Analysis of Parenting Styles}

Parenting style as one of variables in this study was assessed based on our indicators, i.e. the warm approach that their parents have made, their parents always try to harmonize their personal interests and goals with their children's interests, being realistic about their children's competencies, being tolerant when their children made mistakes and educate them not to make the same mistake anymore by not lessening their creativities, initiatives, and imagination. The data sources for the parenting style were the students. The data for parenting style were collected through questionnaire on parenting styles containing 32 questions.

Table 1. Categories of parenting style

\begin{tabular}{|c|c|c|c|c|c|c|c|c|}
\hline No & Indicators & $\begin{array}{l}\text { Zategori } \\
\text { es }\end{array}$ & & & & & $\begin{array}{l}\text { requen } \\
\text { cy }\end{array}$ & \\
\hline & & Excellent 3 & od & Fair & Poor & & $\begin{array}{l}\text { requenc } \\
\mathrm{y}\end{array}$ & $\%$ \\
\hline 1 & $\begin{array}{l}\text { Strict } \\
\text { Parenting }\end{array}$ & 8 & 4 & & 0 & 0 & 12 & 8.82 \\
\hline 2 & $\begin{array}{l}\text { Permissive } \\
\text { Parenting }\end{array}$ & 24 & 6 & & 0 & 0 & 30 & 22.06 \\
\hline 3 & $\begin{array}{l}\text { Democratic } \\
\text { Parenting }\end{array}$ & 74 & 20 & & 0 & 0 & 94 & 690.12 \\
\hline Total & & & & & & & 136 & $100 \%$ \\
\hline
\end{tabular}

Based on the table above, I found that the parenting style of the parents of grade IV students of SDN Gugus Ki Hajar Dewantara in Kendal Regency tended to be included in democratic parenting category. This can be viewed from the greatest percentage lied on the "excellent" category. i.e. $68,38 \%$. This means that the parenting style has significant impact on the students learning outcomes which was marked by the warm approach made by the parents, the parents who always tried to harmonize their personal interests and goals with the interests of the children, their realistic on their children's competencies, and their tolerance when their children made mistakes and then educating them not to make the same mistakes anymore by unlessening their creativities, initiative, and imagination. This is consistent with the statement of Zainudin et al (2012) that the students' academic achievement at school is related closely to the parenting style that their parents apply.

\section{Descriptive Analysis of Learning Motivation}

Learning motivation as a variable of the study was assessed based on six indicators, such as the passion and the desire to succeed, the motivation and the need for learning, the wish for and the dream of the future, the appreciation for the learning, the interesting activities during the learning, and the good learning atmosphere. The data on learning motivation were collected through the questionnaires on learning motivation consisting of 34 questions to answer.

Table 2. Categories for learning motivation

\begin{tabular}{llll}
\hline Interval & \multicolumn{3}{l}{ Frequency } \\
\hline $82-100$ & 75 & $55.15 \%$ & Excellent \\
$63-81$ & 57 & $41.91 \%$ & Good \\
$44-62$ & 4 & $2.94 \%$ & Fair \\
$25-43$ & 0 & $0 \%$ & Poor \\
\hline
\end{tabular}

Based on the table above, it is shown that the learning motivation of the grade IV students of SDN Gugus Ki Hajar Dewantara Kabupaten Kendal is classified into the "excellent" category. This is shown by the greatest percentage was on the "excellent" category, i.e. 55.15\%. It means that the learning motivation has highly significant impact on the students Social Science learning outcomes, which was signed by the passion and the desire to succeed, the motivation of and the need for learning, the wish for and the dream of the better future, the appreciation to the learning, the interesting learning activities, and the good learning atmosphere. This is in line with the statement of Elliot and Dweck (quoted by Bakar 2014) that the learning motivation is the significant factor that is critical to the academic learning and the achievement from kids to adolescence period.

\section{Descriptive Analysis of Social Science Learning Outcomes}

Learning outcomes data for this study consists of cognitive area. 
Table 3. Categories for learning outcomes

\begin{tabular}{|c|c|c|c|}
\hline Interval & Frequency & Percentage & Categories \\
\hline $86-100$ & 96 & $70.59 \%$ & Excellent \\
\hline $71-85$ & 27 & $19.85 \%$ & Good \\
\hline $56-70$ & 10 & $7.35 \%$ & Fair \\
\hline$\leq 55$ & 3 & $2.21 \%$ & Poor \\
\hline
\end{tabular}

Based on the table above, it is shown that Social Science learning outcomes of grade IV students of SDN Gugus Ki Hajar Dewantara, Kendal Regency is classified into "excellent" category. This can be viewed from the greatest percentage which was in "excellent" category, i.e. $70.59 \%$. It means that a few students had excellent learning outcomes although a few others had good, fair, and poor outcomes.

\section{Analysis Precondition Testing}

The analysis precondition testing applied to this study consisted of normality test, linearity test, and multicollinearity test. Based the normality test using One Sample Kolmogorov-Smirnov, viewing value of Asymp. Sig. (2-tailed), I found out that the significance value of parenting styles was 0.073 , that of learning motivation was 0.076 , and that of Social Science learning outcome was 0.064 . Thus, I can draw a conclusion that the distribution of the data for the three variables was normally distributed because the significance was higher than 0,05 .

Based on the linearity test between parenting style and Social Science learning outcomes, I found that the significance value on the column of Deviation from Linearity $0.072>$ 0.05 , it means that parenting style has linear relations with Social Science learning outcomes. Linearity test of learning motivation with Social Science learning outcomes, I got significance value on column of Deviation from Linearity $0.160>0.05$, it means that learning motivation has linear relations with Social Science learning outcomes.

While from the multicollinearity test, I got tolerance value of parenting style on Collinearity Statisticseh column, i.e. $0.583>0.1$ and VIF value given by the assessor was 1.716 $<10$, while tolerance value of learning motivation in Collinearity Statisticseh column was $0.583>0.1$ and the VIF value I got was $1.716<10$. It means that there is not multicollinearity relations between the independent variables.

\section{Hypothesis Testing}

From the correlation testing of product moment in the first hypothesis (Ha1) I found that the value of $r$-count $>r$ table $(0.736>0.176)$ at error rate $5 \%$ and $n=136$ was 0.176 . Level of significance Sig. (2-tailed) shows the less number than a $(0.000<0.005)$. The positive coefficient shows that the two variables have positive or coequal relations, that means that the better the parenting style is, the better the student's learning outcomes are. Based on the research, I can say that the parenting style has positive and significant relations with the Social Science learning outcomes, at correlation coefficient between 0.600 and 0.799 , they have stong relations. This is in line with the study conducted by Krisda Rofa Sadani and Jaino (2017). The study shows that most parents apply the democratic parenting style, and learning outcomes which are classified into "excellent" and "good" categories were got by the students whose parents apply the democratic parenting style.

The results of the second hypothesis testing ( $\left.\mathrm{Ha}_{2}\right)$ can be found that the value of $\mathrm{r}$ count > r-table $(0.725>0.176)$ at error rate $5 \%$ and $n=136$ was 0.176 . Level of significance Sig. (2-tailed) was less than a $(0.000<0.005)$. Positive coefficient value shows that the two variables have positive or coequal relations, which means that the higher the learning motivation, the better the learning outcomes. Based on this study, I can say that learning motivation has positive and significant relations with Social Science learning outcomes, at correlation coefficient between 0.600 and 0.799 , they have close relation. This is in line with the study conducted by Km Sri Susandi Ulandari, et.al.(2014). The study shows that learning motivation has positive relations with the students learning achievement.

From multiple correlation testing in the third hypothesis (Ha3) I found that the value of r-count > r-table $(0.805>0.176)$. Correlation coefficient $(0.805)$ shows that parenting styles and learning motivation have positive and significant relations with the Social Science learning outcomes. By democratic parenting style and high learning motivation, the learning outcomes will improve.

The simple linear regression testing was applied to find how much the contribution of the independent variables to the dependent variable is. This study investigated how great the 
contribution of variable $\mathrm{X}_{1}$ to $\mathrm{Y}$ and variable $\mathrm{X}_{2}$ to $\mathrm{Y}$. Based on the calculation using SPSS 16 for Windows, contribution of $\mathrm{X}_{1}$ to $\mathrm{Y}$ can be viewed from the value of $\mathrm{R}$ Square (0.542). Thus, the parenting style makes contribution to the Social Science learning outcomes as much as $54.2 \%$ and $45.8 \%$ of the Social Science learning outcomes were influenced by the other factors than parenting styles. While contribution of $\mathrm{X}_{2}$ to $\mathrm{Y}$ can be viewed from the value of $\mathrm{R}$ Square (0.525). Thus, learning motivation makes contribution to Social Science learning outcomes as much as $52.5 \%$ and $47,5 \%$ of Social Science learning outcomes were influenced by the other factors than learning motivation.

Multiple regression analysis was used when I aimed to forecast like what the situation (fluctuation) of the dependent variable (criterium) was, if two or more independent variables as predictors were manipulated (the value was fluctuated) as stated by (Sugiyono, 2014). The impact of parenting styles and learning motivation with the Social Science learning outcomes, its R Square was 0.649 at contribution rate $64.9 \%$. I can draw a conclusion that the multiple regression coefficient was significant, which means that parenting styles and learning motivation have significant relations with Social Science learning outcomes, i.e. $64.9 \%$.

\section{Conclusion}

Based on the data analysis and the research, the hypothesis testing, and the discussions, I can draw conclusion that parenting style has positive and significant relation with Social Science learning outcomes at good correlation coefficient, learning motivation has positive and significant relation with Social Science learning outcomes at excellent correlation coefficient.

\section{References}

Bakar, Ramli (2014). The Effect of Learning Motivation on Student's Productive Competencies in Vocational High School, West Sumatra. International Journal of Asian Social Science, 4(6):3.

Bakar, Zaenudin Abu et al (2012). Parenting Style and Its Effect on the Malaysian Primary School Children's School
Perfomance. Social and Behavioral Sciences.

Djamarah, Syaiful B. 2015. Pola Asuh Orang Tua dan Komunikasi dalam Keluarga. Jakarta: Rineka Cipta.

Farzana, et al (2013). Contribution of Parenting Style in life domain of Children. Journal of Humanis And Social Science. 12(2):3.

Harianti, Rini dan Suci Amin (2016). Pola Asuh Orang Tua dan Lingkungan Pembelajaran Terhadap Motivasi Belajar Siswa. Jurnal Curricula. 1(2):1.

Helmawati. 2014. Pendidikan Keluarga dan Praktis. Bandung: Rwmaja Rosdakarya.

Peraturan Pemerintah Nomor 17 Tahun 2010 tentang Pengelolaan dan Penyelenggaraan Pendidikan.

Peraturan Pemerintah Nomor 32 Tahun 2013 pasal $77 \mathrm{i}$ tentang perubahan atas Peraturan Pemerintah Nomor 19 Tahun 2005 tentang standar nasional pendidikan.

Rifa'i, Achmad \& Catharina Tri Ani. 2012. Psikologi Pendidikan. Semarang: UNNES Press.

Sadani, Krisda Rofa dan Jaino (2017). Hubungan Tingkat Pendidikan Dan Pola Asuh Orang Tua Dengan Hasil Belajar. Joyful Learning Jurnal. 6(2):1

Sugiyono. 2014. Statistika untuk Penelitian. Bandung:Alfabeta.

Sugiyono. 2015. Metode Penelitian Kuantitatif, Kualitatif, \& $R \& D$. Bandung:Alfabeta.

Susanto, Ahmad. 2010. Teori Belajar dan Pembelajaran di Sekolah Dasar. Jakarta: Prenadamedia Group.

Ulandari, Km Sri Susandi, dkk (2014). Hubungan Antara Motivasi Belajar Dengan Prestasi Belajar Siswa SD Kelas V Semester Ganjil Di Desa Buruan. Jurnal Mimbar PGSD Universitas Pendidikan. 2(1):1.

Undang-Undang RI Nomor 20 Tahun 2003 Bab II Pasal 3 tentang Sistem Pendidikan Nasional 